\title{
Big Red, Ltd.
}

David J Faulds, University of Louisville, USA

W. Glynn Mangold, Murray State University, USA

P. S. Raju, University of Louisville, USA

\begin{abstract}
This case addresses two frequently heard questions in real-world business settings: "Why are sales going down?" and "What decisions must we make to reverse the sales decline?" These questions were directed to Dr. Felix Wilder, a professor of Marketing, by the senior management of Big Red, Ltd., headquartered in Waco, Texas, after sales reports indicated a significant decline in year-over-year sales in the Louisville, Kentucky, market region. This region represented one of Big Red's most important market areas for soft drinks outside of its home base in Texas. Members of Big Red's senior management team were unable to identify the specific factors that had contributed to the sales decline. As a result, they commissioned Dr. Wilder to conduct an extensive marketing research project to determine the factors contributing to the erosion in sales. Dr. Wilder proposed a multifaceted exploratory research project that involved an extensive review of industry and trade literature, in-depth interviews with grocery store and super center store managers, an in-store consumer survey of Big Red customers, and a consumer focus group. The research design focused on the marketing mix variables, environmental factors, the target market, and changing consumer purchase behavior and lifestyle issues as possible sources contributing to the sales erosion. The results of Dr. Wilder's investigation conflicted with Big Red management's preliminary hypotheses and revealed unexpected factors that may have contributed to the downward drift in sales. Based on the research, Dr. Wilder presented management with various alternative courses of action to correct the sales decline.
\end{abstract}

Keywords: Qualitative Research, Exploratory Research, Marketing Strategy and Planning, Focus Groups

\section{INTRODUCTION}

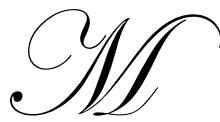

r. Steve "Tiny" Nelson, Vice President of Marketing and Sales for Big Red, Ltd., was pacing in his Waco, Texas, office while gulping a can of Big Red soda and reviewing recent sales figures for the Louisville, Kentucky, market region. As a self-styled Texas good-ole'-boy, Tiny had a commanding presence at 6 feet 2 inches and 270 pounds with his cowboy boots, bolero tie, and thick Texas accent. However, today his good-ole'-boy nature was soured by the sales figures in front of him.

Tiny's reports showed a dramatic year-over-year sales decline for Big Red products in the Louisville market region which included Louisville, Lexington, and Somerset, Kentucky, as well as Seymour, Indiana. The sales trends put a large burr under Tiny's saddle because Louisville was one of Big Red's best markets outside of its home base in Texas. The data indicated that the sales erosion spanned the entire region and was uniform across all package sizes (the sales figures for the Louisville market area are given in Exhibit 1).

Big Red, Ltd., and its wholly owned subsidiary, North American Beverages, Ltd., distributed its products across the United States through a network of independent bottlers. The company was established in 1937 in Waco, Texas, and had expanded its distribution network to 150 regional markets in over 40 states. The Big Red brand competed in the "flavor space" of the soft drink industry, and its personality was as big as the state of Texas itself. Big Red proudly boasted that its soft drink was "America's \# 1 red soda." Its product line consisted of both regular and diet versions and was sold in half-liter, 20-ounce, and 2-liter bottles as well as 6-can, 12-can, 15-can, and 24can packages (the "flagship" packages are shown in Exhibit 2). Important milestones for the company are shown in Exhibit 3. 
Mark Fowler, Big Red's soft spoken CEO, was also rankled about the erosion in sales. "These trends are a problem," he commented in his usual understated manner. "We have to get to the bottom of this and decide how to turn it around." Mark was particularly concerned with the drop-off in sales for the12-can package, which was Big Red's best selling package size. Disturbed by this sudden drop in sales, he told Tiny to track down the reasons for it, a task Tiny took to with the single-mindedness of a Texas Ranger pursuing a cattle rustler.

Tiny quickly rounded up comparative sales data from other regions and "jaw-boned" with fellow managers. Based on this input, Tiny identified several potential factors that he thought may have been responsible for the sales decline. First, Tiny noted that Splenda had been introduced as a sweetening ingredient in Big Red in early 2004. He speculated that this product modification may have contributed to the downturn in sales which first appeared in July of that year. Like his fellow managers, he also thought consumers may have been migrating to other products, notably, store brands. If consumers were migrating to store brands, Tiny feared that they may have begun comparing Big Red's prices to the lower store brand prices rather than to the higher national brand prices with which Big Red historically competed. Tiny also considered that the sales declines may have been due to changes in consumer lifestyles which entailed more emphasis on health conscious behavior. For example, Tiny feared that people may have been switching from soft drinks to bottled water.

After spending considerable time gathering data and talking to Big Red's salespeople and management personnel, Tiny was still perplexed about the nature and scope of the factors that may have affected the sales decline. When Tiny briefed Mark on his progress, he noted that Paul Bruenderman, the Mideast Region Manager, had suggested conducting a short in-store survey of Big Red consumers in the Louisville market. Paul and his staff had developed the questionnaire presented in Exhibit 4 for the in- store survey. Its purpose was to identify the causes of the eroding sales. However, after a few dozen surveys were completed, Paul realized that the results were not providing any meaningful insights into the specific causes of the sales decline.

The erosion in the Louisville market's sales dominated the discussion at the next weekly staff meeting. Mark, Tiny, and Paul expressed frustration about the lack of progress in their efforts to identify the reasons for the sales decline. "Maybe we should bring in a hired gun 'cause we're goin' nowhere fast," Tiny said. At this point in the meeting, Paul indicated that he knew a professor in Kentucky, Dr. Felix Wilder, who had extensive experience as a consultant to the soft drink industry. At Mark's request, Paul arranged a meeting between Dr. Wilder, Tiny, and senior management from the Louisville market area.

The meeting took place on a hot, muggy August afternoon in the board room of the bottling company that distributed Big Red products in the region. As Professor Wilder strolled into the room with a well-worn leather briefcase in his hand, Tiny couldn't help but notice his Ivy League appearance and his neatly pressed pin-stripe suit. At the beginning of the meeting, Tiny grumbled, "This ain't our first rodeo, professor. We all have had more than thirty years experience in this business and these sales trends are throwing us for a loop." Dr. Wilder could see that Tiny, Paul and the other members of the management group were anxious to share their thoughts on the sales decline and its potential causes.

As the discussion unfolded, Tiny expressed his concern that, "We've been enjoy'n double-digit sales growth these past several years 'cross our entire footprint and, now, the wagon's startin' to roll backwards." Tiny also told the professor, "We're 'specially concerned about the 12-can pack 'cause that's been our bread 'n butter for a long time, and the diet product has been growin' faster than the regular soda." Tiny then zeroed in on the purpose of the project, "My daddy always told me, 'Tiny, before you can fix it, you gotta know what's broke' and that's where you come in, Professor. Tell us what's causin' sales to head south so we can figure out how to fix it."

Professor Wilder could sense the tension in the group as Tiny spoke. After listening to their concerns, he straightened his clip-on bow tie and pushed up his horn-rimmed glasses (something he did often) and began to ponder the situation ... After considerable reflection, Dr. Wilder felt that some of Tiny's hypotheses concerning the sales erosion could possibly be discounted. For example, Splenda was introduced as a sweetener in early 2004 but the actual decline in sales did not occur until six months later. This six month time lag between the introduction of a new sweetening ingredient and the erosion in sales suggested that the introduction of Splenda may not have been a cause. 
Based on his extensive knowledge of the industry, Professor Wilder knew that Big Red distributed its products through independent distributors that were responsible for distribution, merchandising, and in-store service. He also knew that Big Red's expenditures on advertising and promotion fell far short of national brand expenditures and that Big Red maintained price points comparable to national brand prices. Furthermore, he knew that the introduction of Splenda as a sweetening ingredient was the only product modification that had been made for either Big Red or Diet Big Red and that the company had added a vanilla flavored drink in 2002. This was the only flavor added to Big Red's product line in the past several years. Professor Wilder also knew that Big Red maintained a relatively small market share in what most industry observers considered to be a mass market.

Finally, Professor Wilder speculated that the sales decline may not have been caused by general economic and climatic conditions or changes in consumer lifestyles. However, the exact nature of the problem and the options for addressing it were not immediately apparent to him.

Given the seriousness of the problem and the level of anxiety Mark, Tiny, and Paul were experiencing, Professor Wilder suggested that he undertake a more extensive investigation to determine the exact causes for the sales erosion before he could intelligently suggest courses of action to reverse the decline.

\section{EXPLORATORY RESEARCH DESIGN}

Recognizing that the reasons for the erosion were not clearly identifiable, Professor Wilder told Tiny that he would like to conduct an exploratory research project to determine the underlying causes of the sales decline and proposed that the research design presented in Exhibit 5 be used as the framework for that investigation. Tiny carefully examined the professor's plan and told him, "The 12-can pack is our prize bull and our sales figures [see Exhibit 1] show it's headin' south. We've all been particularly concerned about the diet product 'cause its been growin,' and this Splenda thing may have ambushed us."

Professor Wilder suggested, "The investigation should begin with an examination of all marketing mix variables and their potential effect on the sales erosion. The research design should explore issues pertaining to pricing, product and packaging, advertising and promotion, distribution and merchandising, and changing consumer lifestyles and preferences as potential factors that may be contributing to the recent erosion in sales." The professor then explained to Tiny that the investigation should be further refined to include the specific points enumerated in Exhibit 6.

These points would be carefully analyzed in a four step sequence which would begin with a series of discussions with key management personnel at Big Red's Louisville distributor along with an extensive review of industry and trade literature. These discussions would be followed by several in-depth interviews with managers of important grocery stores and super centers. The third step, as indicated in Exhibit 5, would consist of an in-store survey of Big Red consumers which would proceed in parallel with the store manager interviews. This was necessary to meet the two-month deadline for completing the research as Tiny had specified. Finally, Professor Wilder recommended that a consumer focus group be conducted to reveal issues which consumers felt affected their purchases of Big Red products, particularly the 12-can package of Diet Big Red.

\section{BACKGROUND RESEARCH}

Professor Wilder met several times with Frank Callaway, the Marketing and Sales Manager for Big Red's distributor in the Louisville market and several of his key management and sales personnel. Based on these discussions, Dr. Wilder was able to determine that during the sales decline there had been no unusual changes in weather or climatic conditions, no changes in the health of the local and regional economies, and no significant changes in the marketing and promotional efforts of national or retailer brands within the region. In addition, the information he gleaned from the discussions with Frank's management team reinforced Tiny's earlier observations about the possible causes of the sales decline. 
The next step in the investigation, a review of industry and trade literature revealed several insights into possible causes for the erosion in sales. However, Dr. Wilder knew that it was unrealistic to expect that a literature review would yield insights into all the specific questions enumerated in Exhibit 6.

Several valuable insights were gleaned from the literature review pertaining to the national soft-drink industry. These insights included the effects of bottled water and alternative beverages on soft-drink sales, consumer life-style trends, and general trends in the national soft-drink market. After carefully sifting through several dozen articles, Professor Wilder was able to distill the content down to the following points that he felt were salient to the investigation.

- In 2004, bottled water sales increased 8.6 percent from the 2003 sales level, making the category the second most popular beverage in the US. Soft drinks remained in the number one position. The bottled water category expanded due to the popularity of flavored waters which increased 48 percent in sales over 2003 levels. Private label bottled water increased 23.7 percent in 2003 and is second to national brand bottled water. Consumers drink bottled water for its perceived purity and healthfulness. Brand loyalty is secondary and consequently consumers are price sensitive. ${ }^{1}$

- $\quad$ Bottled water consumers are younger than carbonated soft drink (CSD) consumers $^{2}$ and maintain more active lifestyles than the average consumer. ${ }^{3}$

- $\quad$ The "New Age" beverages such as energy drinks, sports drinks, RTD teas, and nutrient enhanced fruitdrinks increased 88.5 percent in sales between 1997 and 2003. The key target market for this category is 18 to 24 year old consumers. ${ }^{4}$

- In 2004, the CSD industry posted volume growth of just 1 percent, far below the industry's historic annual growth rate of 2 to 4 percent. ${ }^{5}$ The national brand diet CSDs accounted for the entire category growth rate. ${ }^{6}$

- In 2004, inflation for CSDs increased 2 percent (faster than the general rate of inflation) making consumers more price sensitive. ${ }^{7}$

- In 2004, Splenda was introduced as a sweetener in national brand soft drinks and was found to be extremely popular with consumers. ${ }^{8}$

\section{IN-DEPTH INTERVIEWS WITH STORE MANAGERS}

Big Red products were distributed through a large number of grocery stores, super centers, and convenience stores that were located throughout the Louisville area. Dr. Wilder's experience in the soft drink industry indicated that the managers of these stores were usually very knowledgeable about their products as well as the factors that drove product sales. Therefore, he felt that in-depth interviews with store managers should be an important component in exploring the causes for the sales decline. Mark, Tiny, Paul, and Professor Wilder agreed that these interviews should focus only on grocery stores and super centers because the resources available for the project were limited. They also knew that these two channels accounted for a disproportionate percentage of Big Red's sales and profits (the "80/20" rule was in play).

The in-depth interviews were conducted with the managers of seven stores that were located in the Louisville market. The stores selected for interviews spanned southern Indiana (which constituted the north side of the Louisville market) as well as the south, east, and west sides of town. This selection was intended to minimize geographic bias and also account for the differing demographic composition of the neighborhoods in which these stores were located. Because Professor Wilder knew that store managers were typically very busy, he developed a

\footnotetext{
${ }^{1}$ Beverage Industry," Bottled water tables rise," July 2005, p.24.

2 Beverage Aisle ," Business \& Company Research Center ," August 1999 , p.10.

${ }^{3}$ Beverage Aisle ," Water, water everywhere ," January $15^{\text {th }} 2004$, p.30.

${ }^{4}$ Phillips ,Bob, Beverage Aisle, " Keeping it new, " September $15^{\text {th }}, 2004$, p.26.

${ }^{5}$ Sicher John D, Beverage Digest, “ Beverage Digest /Maxwell Ranks U.S Soft Drinks Industry for 2004,” March $4^{\text {th }}, 2005$.

${ }^{6}$ Beverage Marketing Corporation ," The Top 10 Soft Drink Brands Growth 2000-2004,".

${ }^{7}$ Beverage Marketing Corporation U.S Department of Labor ,Bureau of Labor Statistics.

${ }^{8}$ Beverage Industry, “ The 2005 Soft Drink Report," March 2005, pp 22-30.
} 
standard sequence of questions that was intended to efficiently explore the issues enumerated in Exhibit 6 and could be completed in less than 40 minutes. All interviews were tape recorded.

When Professor Wilder showed up for his 9:45 a.m. appointment with Richard Merton, the first store manager on his list, he noticed that Richard looked a bit tired. "Yeah, I've been here since six o'clock, professor," Richard groaned. Professor Wilder straightened his clip-on bow tie, pushed up his horn-rimmed glasses, and explained the purpose of the visit. When he asked Richard if it was okay to record the conversation, Richard replied, "That's not a problem, professor. In fact, this is very important and I am anxious for my comments to go in your research." Within two minutes, Richard was candidly offering information on each of the major topics summarized in Exhibit 6. The remaining six store managers on Professor Wilder's list also displayed a similar level of enthusiasm for the research.

After completing the seven interviews, Professor Wilder divided his research staff into two teams. Each team independently analyzed the tapes of the store manager interviews and highlighted the important comments. The teams then compared their analyses to ensure that all relevant points were included and that the store managers' comments were interpreted correctly. The results are summarized in Exhibit 7.

\section{IN-STORE CONSUMER SURVEY}

Although the information from the store managers was quite useful, Professor Wilder recognized that consumer perceptions were critical to the success of the soft drink industry. However, gathering consumer data pertaining to Big Red would be problematic. A random survey of consumers living or working in the Louisville market area would be very expensive since only four percent of the general population was Big Red consumers. Professor Wilder also knew that many of the people contacted would refuse to participate in the survey; thus, an extremely large number of people would have to be contacted in order to generate a single response.

Consequently, Dr. Wilder decided that a two-stage sampling plan would be appropriate. The first stage entailed selecting a judgment sample of nine stores--four super centers and five grocery stores--which were spread throughout the Louisville market. Paul, Frank, and Professor Wilder selected these stores based on several criteria. First, the number of stores that could be selected was limited by the research budget Tiny had made available. Second, Paul and Frank indicated that the sales trends for Big Red products in these nine stores mirrored the market region's overall downward trend. Third, the stores were located in different geographic areas and catered to different demographic segments. Finally, Paul and Frank were confident that the managers of these stores would be willing to have Professor Wilder's interviewers conduct surveys on their premises.

Dr. Wilder developed the questionnaire presented in Exhibit 8 for the second stage of the in-store survey. Tiny and Paul reviewed the questionnaire and made several minor suggestions for improvement. Their suggestions were incorporated and the questionnaire was carefully pre-tested to ensure that respondents would understand the questions, that the questions flowed logically, and that the interview could be conducted in five minutes or less.

A convenience sample was employed to select consumers of Big Red products. People who were observed to be in the process of buying a Big Red product in one of the nine stores were approached by a trained interviewer and asked to participate in the survey. Those who participated were offered a free 2-liter bottle of Big Red. Over a two-week time period, 161 useable questionnaires were obtained. Selected survey results are presented in Exhibit 9.

\section{CONSUMER FOCUS GROUP}

Professor Wilder was aware that the in-store consumer survey would provide valuable insights into the consumption of Big Red products. However, he had anticipated that the survey would not provide an in-depth understanding of the reasons behind the erosion of Big Red sales. He felt that the best way to gain this understanding would be to talk to consumers directly. A focus group would provide the forum to explore such issues as the reasons why consumers drink Big Red, how the product fits into the mix of other types of soft-drinks, and the detailed image of Big Red. 
Horizons Research, International, a Louisville based market research firm, conducted the focus group under Professor Wilder's direction. Professor Wilder had a long-standing consulting relationship with Horizons Research and knew they had excellent focus group facilities and a superb track record for conducting focus groups.

Jim Wilhelm, the Senior Vice-President for Horizons and an experienced focus group moderator, was chosen to conduct the focus group. Jim kept the focus group discussion on track by using a discussion guide that he and Dr. Wilder had developed. This guide addressed: (i) general consumption behavior for non-alcoholic refreshment beverages, (ii) purchasing and consumption dynamics for Big Red, (iii) pricing issues, (iv) distribution and merchandising issues, (v) and promotional issues to name a few.

Professor Wilder and Jim decided to screen potential participants on several criteria. First, they decided the participants should be between 21 and 65 years of age. Second, both males and females should be represented. Weekly consumption patterns for Big Red products constituted another important criterion. Specifically, Professor Wilder and Jim decided to limit the focus group to individuals who (i) either drank 4 or more servings of Regular or Diet Big Red per week, or (ii) individuals who had previously drank 4 or more servings of Regular or Diet Big Red in a two-week period but had recently reduced their consumption. Based on these criteria, 16 people were selected to participate in the focus group.

These participants were invited to dinner at the research facility prior to the focus group. This dinner gave Jim and Professor Wilder an opportunity to observe these 16 individuals' personalities and their interactions with one another. Ten people were then selected for the focus group based on their perceived ability to contribute to the focus group discussion. ${ }^{9}$ All 16 individuals invited to dinner received a $\$ 75$ honorarium.

About half an hour before the focus group convened, Mark, Tiny, Paul, Frank, and other members of the Big Red management team entered the observation room in the focus group facility. Professor Wilder and three members of his research staff joined the group. There, the focus group observers were greeted by a Texas sized barbeque dinner and a variety of domestic and imported beers. Upon seeing the impressive spread, Tiny let out a loud laugh and said, "Someone must be gettin' either married or buried here tonight!" Professor Wilder then introduced Tiny to the members of his research staff and they all mingled for a few minutes before taking their places in the leather chairs in the terraced observation room.

The focus group began with Jim Wilhelm introducing the ten participants. Jim pointed to the mirror on the wall behind him and said, "Folks, I would like you to know this discussion is being observed by several Big Red officials who are situated on the other side of the one-way mirror behind me." He then pointed to a recording device mounted on the ceiling above them and said, "The session is also being recorded on both audio and video tape which will be supplied to Big Red officials after our discussion." Within a few minutes the flow of the conversation suggested that the participants had forgotten about the people behind the one-way mirror and the recording devices. After 90 minutes Jim brought the discussion to a close by asking the respondents to write down their answer to the following two questions:

- "If Big Red were an animal, what type animal would it be and why ${ }^{10}$ ?"

- "What does Big Red need to do to increase its sales, particularly from people like yourself ${ }^{11}$ ?"

Similar to the store manager interviews, Professor Wilder divided his research staff into two review teams each consisting of two individuals. Each team separately analyzed the video tape of the focus group discussion and took careful notes regarding their observations. The teams then compared their notes and produced a final summary addressing the important points and comments from the focus group. These points are summarized in Exhibit 10.

\footnotetext{
${ }^{9}$ The focus group discussion guide is available in the Instructor's Manual.

10 The most frequent responses to this question were an elephant and a horse. The justification offered by the focus group participants for both responses was that the size of each animal corresponded to the size of the brand name, "Big Red."

${ }^{11}$ The two most frequently offered suggestions were to make the product "consistently" available in the grocery store and to expand Big Red's product line with more flavors.
} 
Over the next three weeks Professor Wilder wrote his report summarizing and synthesizing his research results. The 60-page report would be used for his forthcoming presentation to Big Red management.

\section{DR. WILDER'S PRESENTATION}

As Mark, Tiny, and Don Sharp (Chairman of Big Red's Board of Directors) descended into Louisville's Standiford International Airport on the Big Red corporate jet, Tiny tried to prepare Don for his meeting with Dr. Wilder and the upcoming presentation. "Felix is a very smart and thorough fellah, but he's from back east, New York or somewhere, and he don't talk the way we do in Texas ... 'fact is, that ole boy is 'bout as dry as a Texas dust storm!"

A few minutes later, the three Texans, all clad in business suits, Stetsons, and cowboy boots, were walking through the terminal to meet their chartered limousine. While they were admiring the airport's colorful display of jockey silks from Churchill Downs, Mark mentioned that it would be only a short 15-minute ride to the Seelbach Hotel in downtown Louisville, where the professor would be giving his presentation. Don remembered reading about the Seelbach in F. Scott Fitzgerald's classic novel, The Great Gatsby, and wondered out loud if the opulent old hotel would look as he had pictured it in his mind.

\section{Exhibit 1 Sales Trend for Louisville Market Area: By Package Size}

Louisville, Kentucky

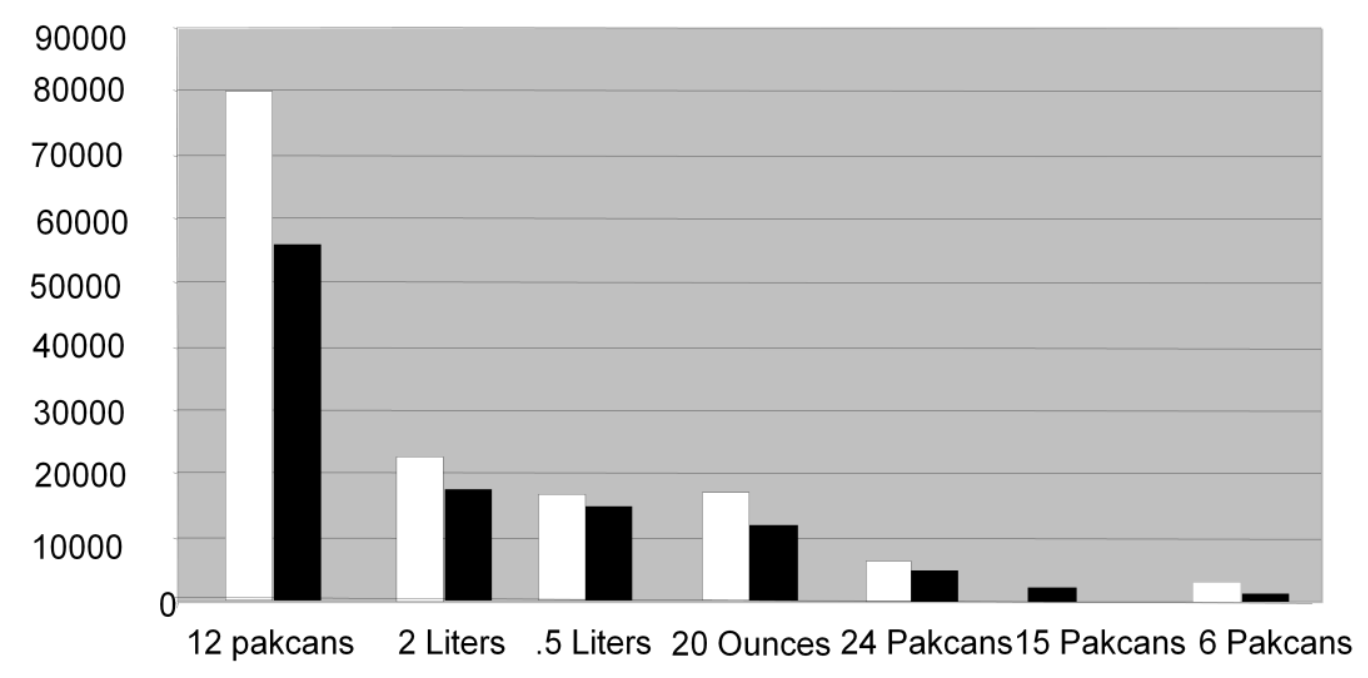

2004 - 2005

The group was met by Dr. Wilder and his research staff as they passed under the ornate crystal chandelier in the Seelbach's grand lobby. The Louisville distributor's management team had already arrived in the walnutpaneled conference room which was elegantly appointed and thoroughly prepared by the Seelbach staff. A large conference table, surrounded by two dozen leather-padded chairs, sat in the center of the room, with a computer, projector, and screen at the head of the table. Another table, draped with fine white linen, anchored the room's back wall. A huge bouquet of yellow roses was prominently displayed in the center of the table and was surrounded by a lavish assortment of hors d'oeuvres, Kentucky's best "bourbon 'sippin whiskies," and a variety of wine and imported beer. 
About two hours later, the methodical Dr. Wilder brought his presentation to a close. Don glanced around the table and took notice of the enticing refreshments in the back of the room. He cleared his throat and said, "Professor, you did a fine job with your research and you have helped us better understand our problems. Your recommendations about where we should go from here make a lot of sense..." Before Don could finish complimenting Dr. Wilder, people began making their way toward "the big waterin' hole" in the back of the room.

Tiny, however, remained alone at the conference table, poring over the report in front of him and reflecting on Dr. Wilder's presentation. Dr. Wilder had identified several important factors that had contributed to the sales erosion. Tiny knew that he would need to provide Mark with a focused decision that included strategic options for reversing the sales decline.

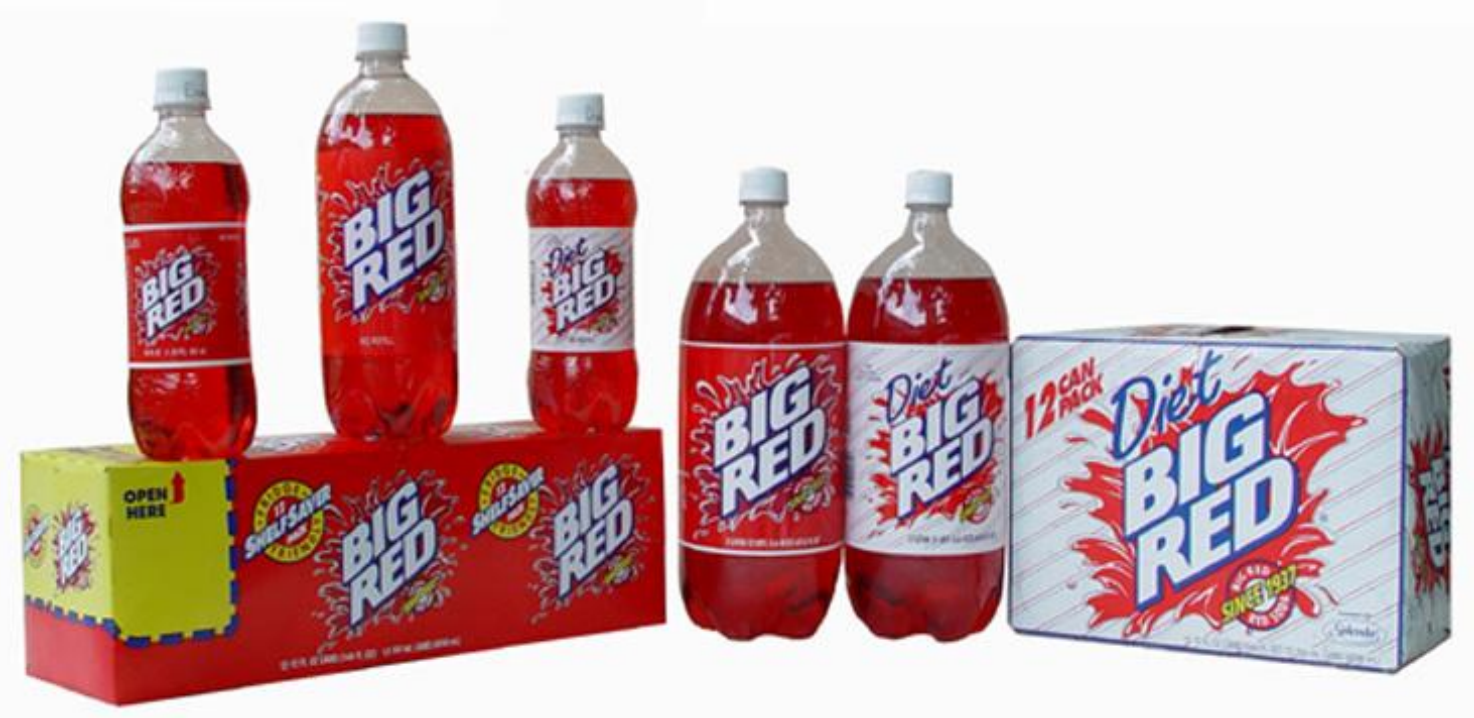

Exhibit 3 Important Milestones for Big Red, Ltd.

1937 -- Perfection Barber and Beauty Supply in Waco, Texas begin making flavoring extracts under the name Sun Tang. Inventors Grover Thomsen and R.H. Roark develop a unique red drink, Sun Tang Red Cream Soda. They change the company name to Perfection Co. Ltd. to be more in line with a flavoring extract business.

1939 -- Trademark is registered for Sun Tang Red Cream Soda.

1959 -- Sun Tang Red Cream Soda becomes Sun Tang Big Red

1969 -- Trademark is registered for Big Red.

1972 -- Company moves headquarters to 720 Jewel Drive from downtown Waco.

1973 -- Corporation name changes to Big Red, Inc.

1976 -- President M.L. Saunders dies. Donald S. Sharp comes in as Executive Vice President 
1977 -- Big Red begins 20-year expansion program adding bottling franchises in more than 13 states.

1997 -- Big Red introduces Splash Logo

2002 -- Don Sharp inducted into Beverage World magazine's soft Drink Hall of Fame.

2002 - Big Red introduces vanilla flavored Big Red .

2004 -- Big Red float debuts at the Kentucky Derby.

2005 -- Big Red ranks as sixth-largest carbonated drink company in the country.

2006 - Big Red products are distributed in 150 regional markets in over 40 states

Exhibit 4 Questionnaire Developed by Big Red Management

I. What Diet drinks do you purchase on a regular basis?

1 2 3

II. Which packages do you purchase when you buy Diet Drinks?

Cans

20 oz bottles

2-liter

Other

III. How does being in the ad influence you? What else influences your buying decision in choosing a package?

At the Grocery store

At the Convenience store

Other places

IV. If you used to drink Diet Big Red, why did you stop drinking it?

1

2

3

V. If you used to drink Diet Big Red and you drink less now, what brand(s) did you switch to and why?

1

Brand Reason to change

2

3 
Did you know Diet big Red s sweetened with $100 \%$ Splenda? Yes $\quad$ No

Comments

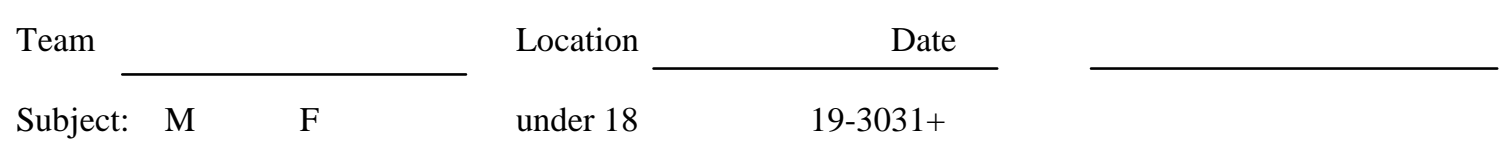

Exhibit 5 Research Design

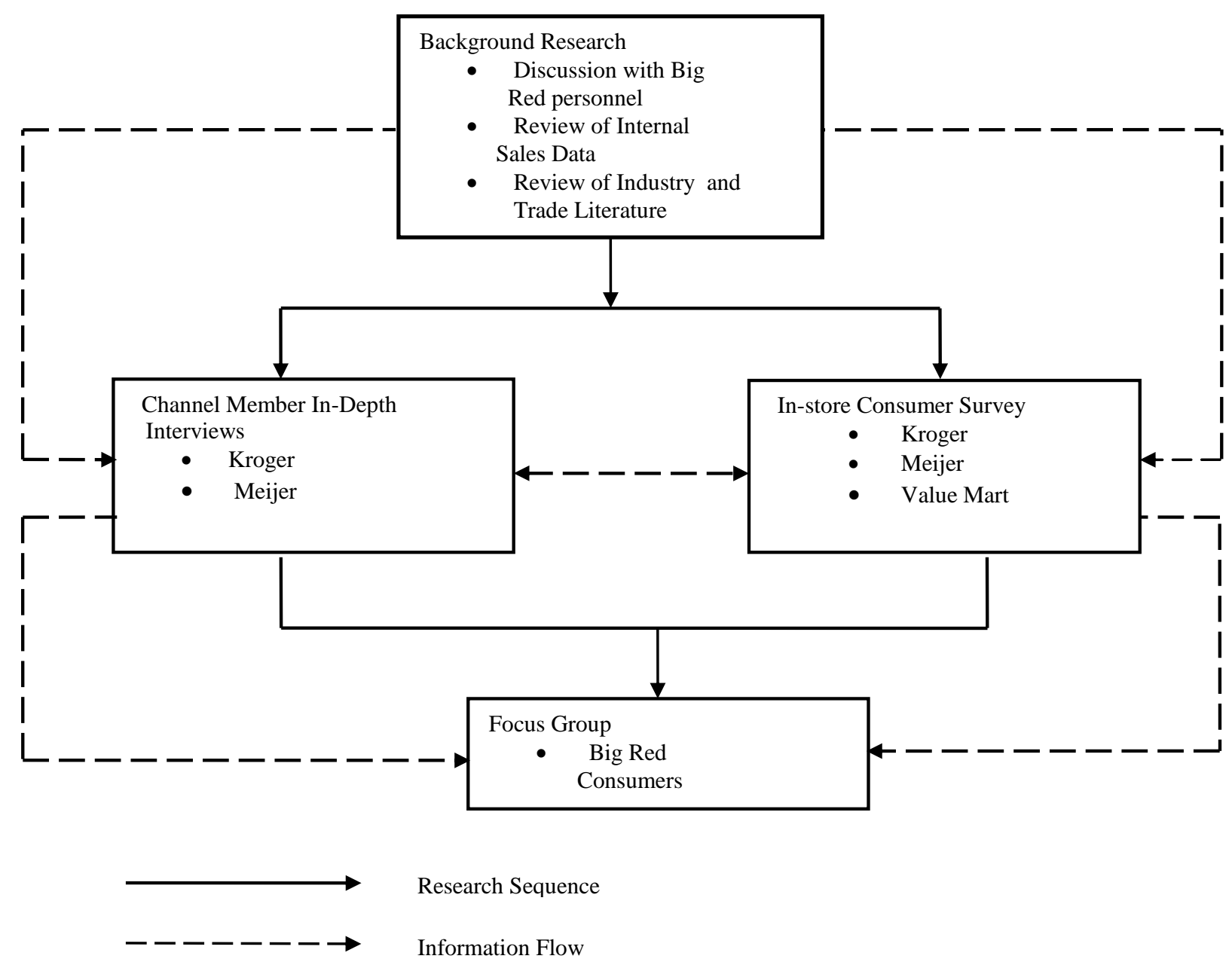

Exhibit 6 The Focus of the Investigation

\section{General Consumer Purchase Behavior and Lifestyle Issues:}

- Has the trend toward the use of products promoting healthier lifestyles affected the sales of Big Red?

- Have consumers reduced their consumption of carbonated soft drinks or switched to other types of beverages? 


\section{Pricing Issues:}

- $\quad$ How important is price to Big Red consumers in the overall purchase decision?

- Do consumers believe that the current price of Big Red is a "fair" price compared to the price of other softdrinks or beverages?

- How price sensitive are Big Red consumers?

- $\quad$ Do Big Red consumers stock-up when price deals are offered?

\section{Product and Packaging Issues:}

- How loyal are consumers to Big Red products?

- $\quad$ Does product loyalty vary between Regular Big Red and Diet Big Red consumers?

- Have Big Red consumers noticed any recent change in the taste of Big Red products? If so, has the change improved the taste of the product?

- $\quad$ Are Diet Big Red consumers aware that "Splenda" is used as a sweetening ingredient in Diet Big Red?

- Has the use of "Splenda" improved the taste of Diet Big Red?

- Have recent product entries (store brands or national brands) in the "flavor" space (e.g., grape, red, lemonlime flavors) of the soft drink market eroded Big Red's consumer base?

- $\quad$ How do consumers feel about Big Red products' various package sizes (e.g., 12-can pack, 2-liter, etc.)?

- How do consumers feel about Big Red's existing product line? Should Big Red expand the product offerings to include other flavors?

\section{Advertising and Promotional Issues:}

- $\quad$ Are consumers aware of Big Red's advertising and promotional efforts?

- How important are promotional factors such as coupons, contests, end-of-aisle displays, and ads in the weekly shopper in influencing Big Red consumers to buy the product?

- What types of promotional efforts are most effective for stimulating sales?

\section{Distribution and Merchandising Issues:}

- $\quad$ Are Big Red products available to the consumer in the right quantity and at the right time?

- $\quad$ Are Big Red in-store displays effective in attracting consumers and increasing sales?

- $\quad$ Do grocery store managers experience distribution related problems with Big Red products?

Note: The term "Big Red" is used to refer to consumers of both the regular and diet versions of the product. The above points represent a partial list of the major issues in the investigation and are intended to give an overview of the types of topics explored by Dr.Wilder.

\section{Exhibit 7 Summary of In-Depth Interviews with Store Managers}

\section{General Consumer Purchase Behavior and Lifestyle Issues:}

- $\quad$ "The bottled water business has had a large impact ... almost a reciprocal decline in the soda business ... diet soft drinks have become stronger, a trend that has gone on for the last couple of years."

- "There are a variety of choices out there, kids are drinking more energy drinks."

- $\quad$ "Diet Big Red has a niche market and store brands don't have a huge presence in the red flavor space ... and there is no diet offering in the store brand flavor space ... and the Diet Big Red has the greatest opportunity for growth."

- "Demographics, all soda is getting to be a product for lower income groups, higher income groups tend to buy diet soda."

- $\quad$ "People are steering toward water today....people are more health conscious today."

- $\quad$ "I don't know who Big Red is trying to go after, the high/low/medium age bracket... I can't tell you who they are going after." 
- $\quad$ "It is unbelievable how much water we sell, but that is more of a convenience thing...bottled water is a lifestyle thing."

\section{Pricing Issues:}

- $\quad$ "Price of Big Red is competitive... the private label brands have become stronger in quality and taste with the red flavors... a private label 12-pack is $\$ 1.99$ everyday, and Big Red is $\$ 3.49$, when it is featured it is around $\$ 2.50$. So it makes the private label more inviting to the consumer."

- " $\quad$ "People have become very price conscious, people buy exactly what is on sale or what is hip."

- $\quad$ "Our product sells for $\$ 1.97$ every day... Big Red 12-pack sells for \$3.19. If Big Red is on sale, their sales volume goes up ... a big stocking up effect occurs with Big Red.”

- " "I think Big Red is competing with store brands and they move product when the price is reduced."

- $\quad$ "There is some brand loyalty in soft drinks....there are cherry pickers that will go to where the price is...we run price deals often...Diet Big Red or Regular Big Red for the 12-can pack would have to be at $\$ 2.50$ or lower to really significantly move the product."

- $\quad$ "Their [Big Red] distributor does well with Big Red and it will far out sell any of the other flavors when it is on sale ... Big Red will dominate all the flavors."

- $\quad$ "Price could tip the scale for Big Red if they were more aggressive on price.... when it is on sale it really takes off....Coke and Pepsi drinkers are less price conscious, with Coke being the least price conscious."

\section{Product and Packaging Issues:}

- $\quad$ "I believe Big Red competes with private labels... flavors compete with private labels and the colas like Pepsi and Coke are not the competition for the flavors like Big Red."

- "Splenda has made all the diet products better... as a sweetener it has moved up to the number one sugar substitute...consumers are embracing Splenda and it probably has improved the taste of Diet Big Red."

- $\quad$ "Splenda, I don't know how it has influenced sales for Big Red, but for other products that use Splenda, it has increased the sales of those products... and the impact I would say is more positive than negative."

- $\quad$ "Big Red does not compete with our store brand soft drinks."

- $\quad$ "I think a lot of people have a red cream soda like Big Red, but Big Red is the biggest label the Big Red distributor carries.... flavors other than Big Red really haven't grown at the store level...not a lot of movement with the grape soda and other flavors not a tremendous amount of movement."

- $\quad$ "Big Red competes more against the national brands than they do with the store brands."

- " $\quad$ "12-can packs and 24-can packs are as strong as ever, we are selling a lot of bottles but it is not eroding the cans.... people are getting away from the 2-liter for all CSD's [carbonated soft drinks].”

- " $\quad$ "The 12-can pack gives customers more ability to serve more people."

- "Big Red should expand its product line to include other flavors."

- $\quad$ "Big Red is the most popular cream soda flavored product on the market and they should think about introducing other cream flavored sodas in the flavor category."

- $\quad$ "I would suggest that they look at bringing out more flavors and offer their consumers more variety...now they just have red flavored soft drinks, but other flavors would make them more competitive."

- $\quad$ "They [Big Red] should be more aggressive in their product offerings....they lag behind in being innovators in developing new flavors and products."

\section{Advertising and Promotional Issues:}

- "I have never seen a Big Red commercial nationally, and advertising will increase your sales."

- $\quad$ "My recommendation is that they need to make people aware of their products, there is no advertising, no P.O.P. advertising, sampling would help, taste testing would help, they [Big Red] must build awareness of their product."

- $\quad$ "They [Big Red] must decide what market they are going after, what age group are they going after....they must establish themselves as a brand ... if they want the flavor market, go after it ... they can't compete with Pepsi or Coke in the cola market."

- "We don't do as many displays for Big Red because Coke and Pepsi displays generate more sales." 
- $\quad$ "Big Red is usually last in a three way race when nothing is featured ... I don't know if advertising [Big Red] would help or not.... when we have Big Red featured and displayed we do sell a lot....to survive [Big Red] will have to discount more than Pepsi and Coke to get retailers attention."

- $\quad$ "Diet Big Red could grow sales through marketing and advertising, getting the name out to the consumer and increasing the level of awareness for the brand."

- $\quad$ "They [Big Red] do not do enough advertising and promotions and they are just maintaining themselves....they should publicize themselves more in order to grow."

\section{Distribution and Merchandising Issues:}

- "Their [Big Red] decline is due to their salesmen and their merchandising....they have done a good job over the last 6 months, before that they were very bad...their in-store merchandising is not good, Big Red is often mixed in the middle of a floor display and it doesn't move that well because consumers don't see it $\ldots$ the products that are in highest demand should be in the middle of the display and the lesser ones on the end of the display...they build the displays and they are not too sophisticated at that, most of their merchandisers are old school... all displays should lead off with Big Red."

- $\quad$ "It is about display ... where they [Big Red] are located in the store and featured...you can really impact the consumer and drive them to your product with your display location...the big display on the side is what is seen. Consumers don't see Big Red's displays on the floor because they are often in the wrong location and Big Red is often hidden in the display."

- " "If they [Big Red] improved their in-store merchandising you would see a 50 percent increase in sales."

- $\quad$ "In in-store merchandising they are not very good at all...this is costing them an astronomical amount in lost sales...they are not my choice to do business with...I would not partner with them..."

- $\quad$ "They have the number one position in the aisle, which is not the best spot because when you are three feet into the aisle, you have already past them, they have 12 feet of shelf space in our store...Pepsi and Coke each have 32 feet."

- $\quad$ "They should increase their service level because they already have a niche with Big Red so they must get people [store managers and stock room people] that want to work with them."

- $\quad$ "In in-store merchandising [Big Red] is on the bottom of the list....I was going to remove them from my store...I have told them this and they have gotten 50 percent better....I think they are losing about 50 percent of their sales because the product is not on the floor...they do have a distribution problem, absolutely...inventory management ... their merchandisers, they don't put the product on the shelf....they don't balance what they need in the building with what is in the building...if they improved they would get more loyalty and sales, it would be a win-win situation for both of us....I would be willing to help them improve this aspect of their business....Pepsi and Coke salespeople will stop in but the Big Red's rep, I would not recognize him."

- $\quad$ "If you look at the facings for Big Red they may have one or two, the big boys have the space because they can keep it up....I have not been in a market in the last 15 years where I have had great service from a Big Red distributor."

- $\quad$ "I don't think they have the staff to do big sales, what we call second shot or third shot displays (follow up displays), they would have to up their staff ...they must have ability to have the product in the store and on the shelf...for the sales volume they are at now they are OK, but at increased volume they would be in trouble...you don't want a hot feature with no product in the store or sitting in the back room ... when they do it short term (promotions lasting a few days) they do fine."

- $\quad$ "In this store service speaks a lot, if they give me good service I give them more displays and display space."

- $\quad$ "Big Red has more stock-outs than Pepsi and Coke, particularly when they are on display or sale...we have had people complain about the stock-outs for Big Red.... and if the product is not on the shelf it looks bad for our store too.... if the product is on sale or display, we need superior service at that time....I would say Big Red is losing 5 percent of sales because of stock-outs during display periods....their display they had last week is down because they could not keep the product out on the shelf, the product is not in the backroom or out on the floor." 
Exhibit 8 Dr. Wilder's In-Store Consumer Questionnaire

Section I: General Consumer Purchase Behavior

1. What Big Red product do you buy most often for yourself to drink? Regular Big Red

Diet Big Red

Caffeine Free Diet Big Red

Big Red Float

None[quit]

2. For the Big Red product you buy most often, [interviewer will name product identified in $Q$. 1] would you describe yourself as being?

Heavy user

Moderate user

Light user

3. Describe your level of loyalty to Big Red products?

Not loyal

Somewhat loyal

Very loyal

4. For the Big Red product you buy most often, [interviewer will name that product from list in $Q .1$ ], in what size do you buy most frequently? 12 can package 20 oz bottle

2-liter bottle

$1 / 2$ liter bottle

24 can package

$1 / 2$ liter 6-pack

Other

5. For the Big Red product you buy most often, [interviewer will name that product from list in $Q$. 1], have you recently reduced the amount of that product you buy?

${ }_{-}$Yes ___ No

[If Yes, go to Q. 6, If No, proceed to Q. 9]

6. Why have you reduced the amount that you buy?

[If answer to Q. 1 was Diet Big Red proceed to $Q .7$ and $Q$. 8; otherwise, skip to Q. 9]
7. Have you switched from Diet Big Red to any other brands of diet soft drinks? Yes No

8. What brand or brands have you switched to?

Section II: Product and Packaging Issues

9. For the Big Red product you buy most often [interviewer will name product identified in $Q$. 1], have you noticed any change in the taste of that product? Yes No

[If they purchase Diet Big Red most often, proceed to $Q$. 11]

10. In your opinion, does Big Red Taste better Taste worse No difference in taste

11. Did you know that Diet Big Red is sweetened with $100 \%$ Splenda? Yes No

[If Yes, proceed to Q. 12]

12. In your opinion, has Splenda made Diet Big Red

Taste better

Taste worse

No difference in taste

Section III: Pricing Issues

13. How important is the price of soft drinks to you in your purchasing decisions? Very important Somewhat important Not important

14. Do you believe the current price of the Big Red product you buy most often [interviewer will point to the package size and flavor] is a fair price?

Fair price

Neutral

Not a fair price 
15. When the price of the Big Red product you most frequently buy is reduced [interviewer will name that product and package size], do you stock up on that product?

$$
\text { Yes }
$$
No

Section IV: Advertising and Promotional Issues

16. How important are promotional factors such as coupons, contests, end-of-aisle displays, and ads in the weekly shopper in influencing your purchasing decisions for soft drinks?

Very important

Somewhat important

Not important

17. Which of the following promotional factors would influence you to buy more of your favorite Big Red product? [check all that apply]

Coupons

Contests/sweepstakes/games

End-of-aisle displays with reduced retail price.

Ads in the weekly shopper or newspaper

18. Which of the following promotional items have you recently seen or heard for Big Red products? [check all that apply] Billboards

Television Commercials Radio

Ads other than weekly shopper Features in the weekly shopper Other

I have not seen any of the above

Section V: Distribution and Merchandising Issues

19. How often have you been in the supermarket and found that Big Red products were not available on the shelf or out-of-stock?

Never

Rarely

Often

Almost always
20. Do you find it difficult to locate Big Red products in the soft drink aisle of your supermarket?

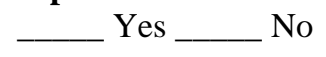

21. Would you purchase more Big Red products if they were displayed in special locations in your supermarket such as end-of-aisle displays? Yes No

\section{[To Be Said By Interviewer]}

Thank you for your generous cooperation. I have just one more piece of information I would like to collect from you. It will only take a minute.

\section{Section VI: Focus Group Participation}

22. How likely would you be to participate in a focus group for which you would be paid $\$ 75$ to share your thoughts and opinions on Big Red with us? The focus group would be held in the evening around 7 o'clock here in Louisville?

I would participate

Very likely to participate Somewhat likely to participate Not likely to participate I would not participate

[If they would participate or are Very Likely or Somewhat Likely to Participate, proceed to $Q$. 23, if not go to $Q .25$ ]

23. What days of the week would be best for you? [check two days]

$$
{ }_{-} \mathrm{M}_{-} \mathrm{T} \_\mathrm{W} \_\mathrm{Th}
$$

24. Would you participate in a focus group on Tuesday, December $13^{\text {th? }}$ Yes No

25. Sex of the respondent is: Female Male

26. Race of respondent is: Caucasian African-American Hispanic Asian/Pacific Islander Other 
27. What category best describes your age?

28. What category best describes your household family size including yourself?

29. What category best describes your annual household income?
Finally, may we get your:

Name:

Zip Code:

Telephone Number:

What time is best to contact you?:

\section{To Be Completed by Interviewer:}

Name:

Store:

Date:

Time:

Exhibit 9 Selected Results of In-store Consumer Survey

\section{Comparison of Regular Big Red versus Diet Big Red}
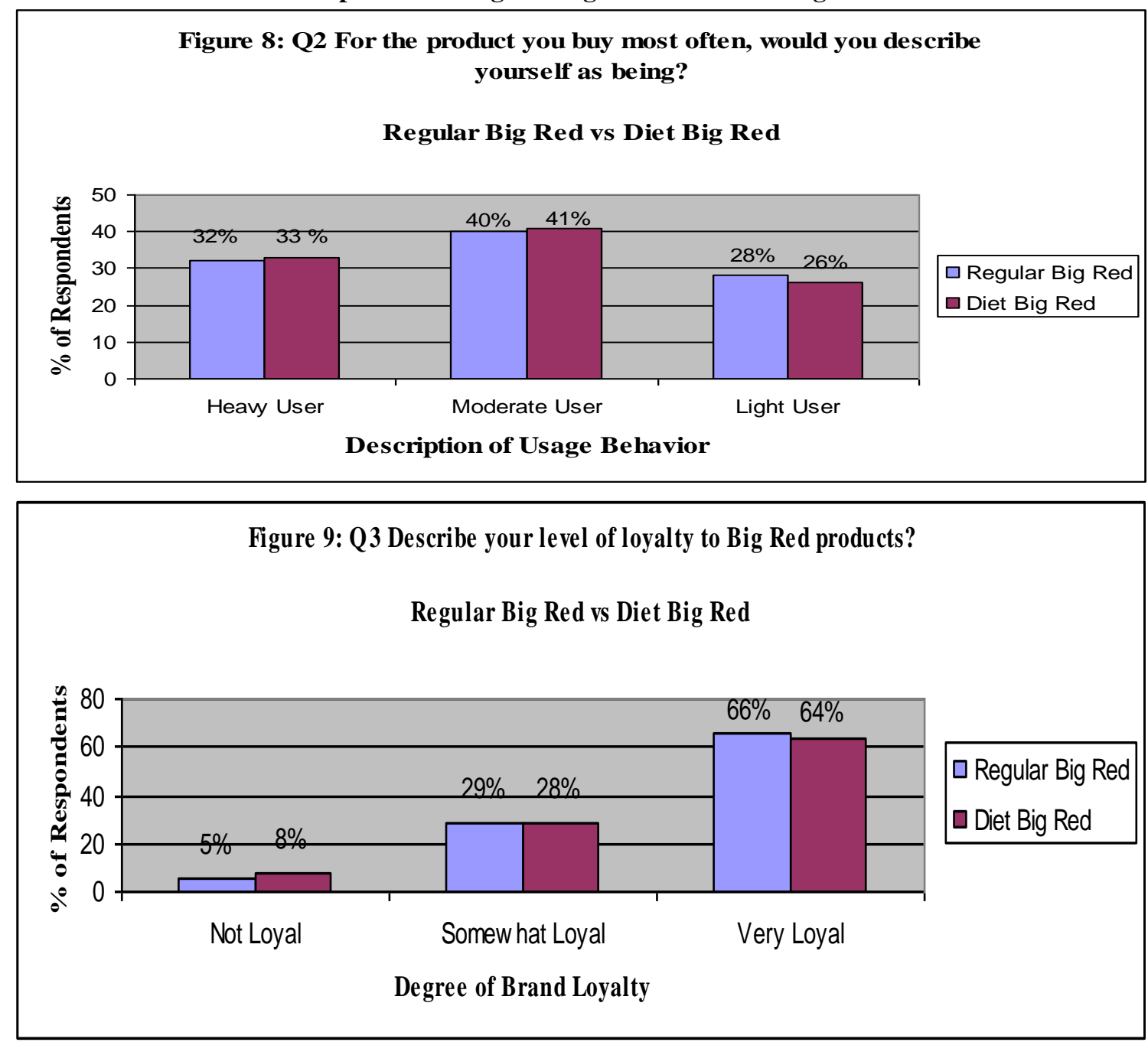

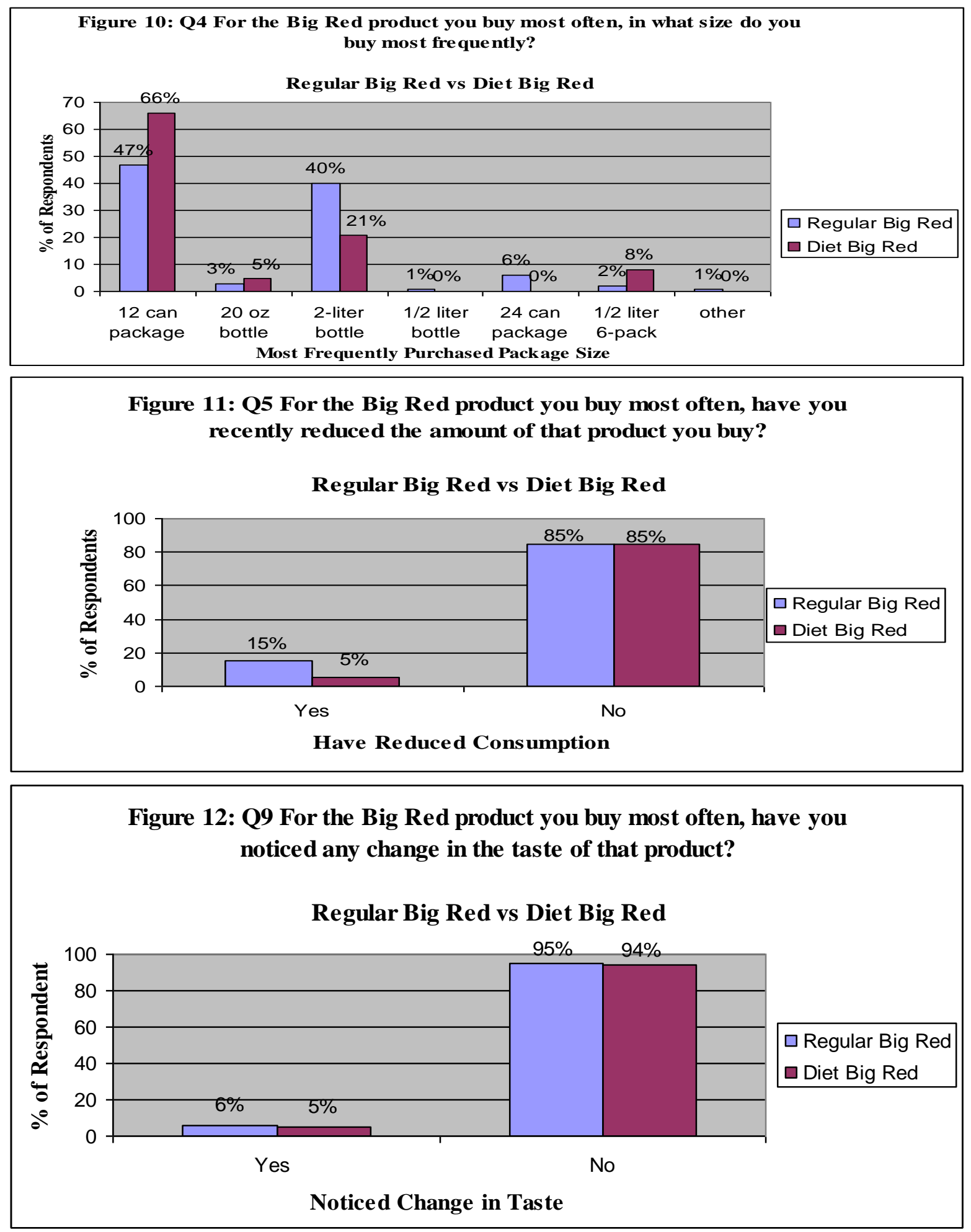

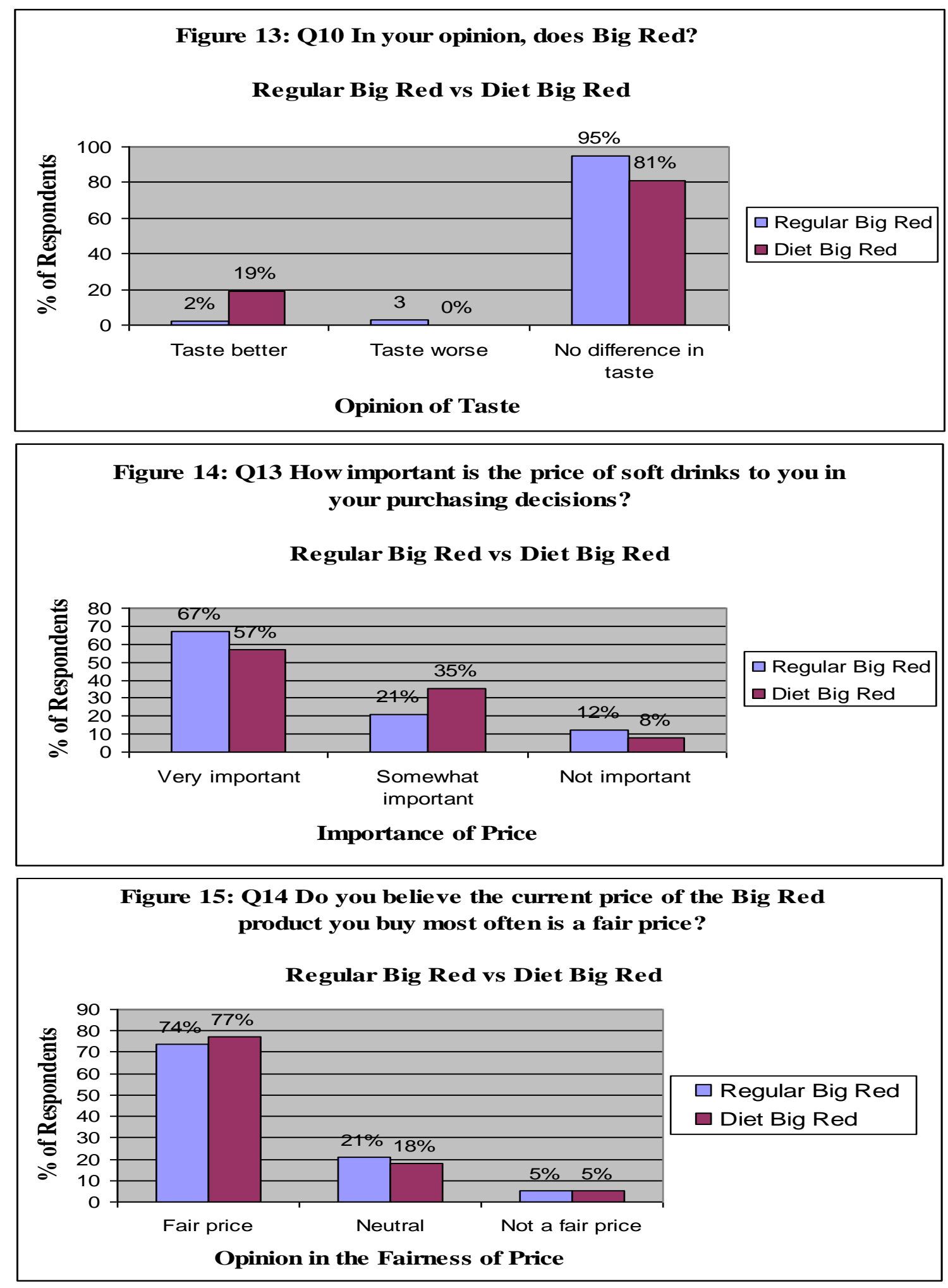
Figure 16: Q15 When the price of the Big Red product you most frequently buy is reduced, do you stock-up on that product?
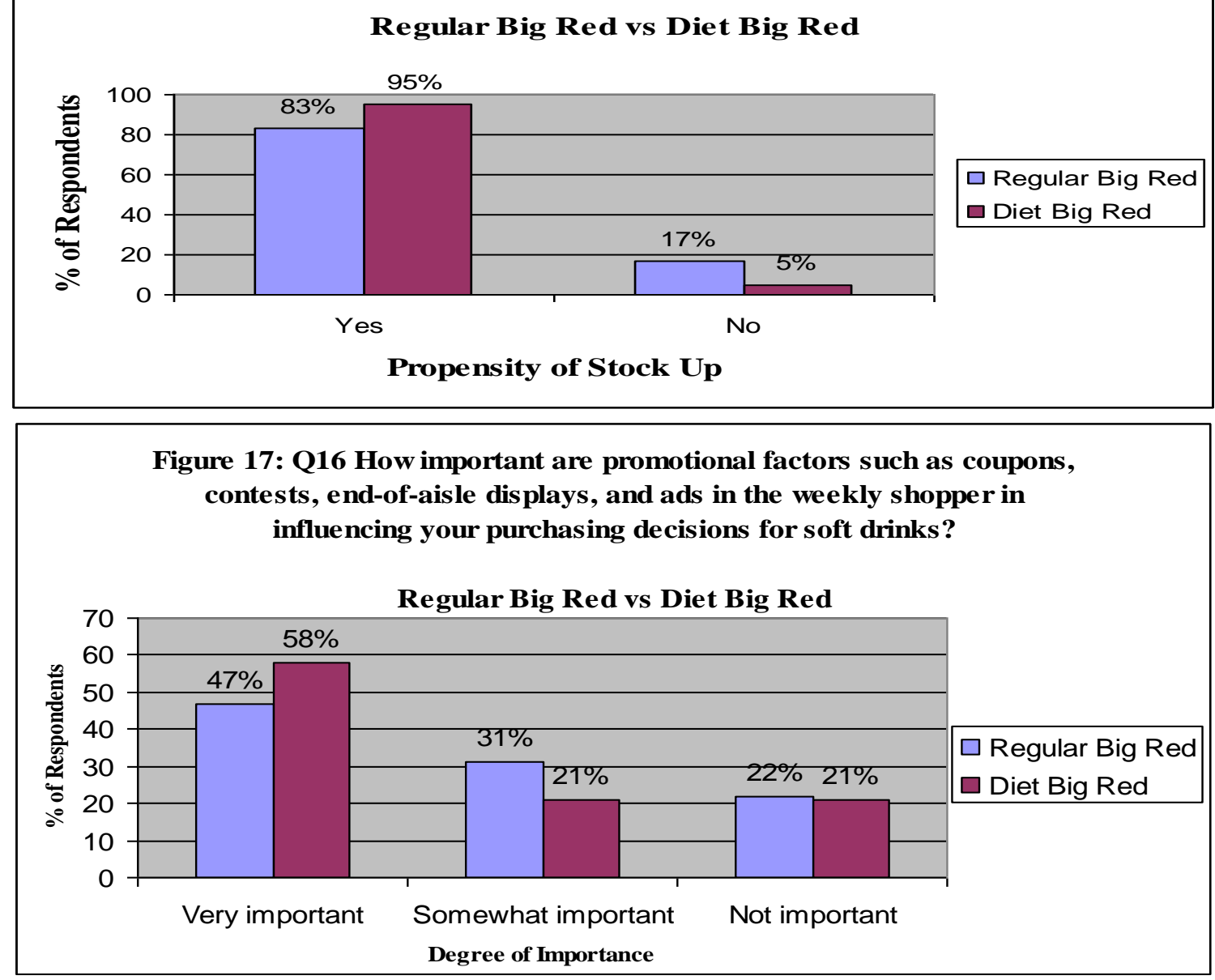
Figure 18: Q17 Which of the following promotional factors would influence you to buy more of your favorite Big Red product?

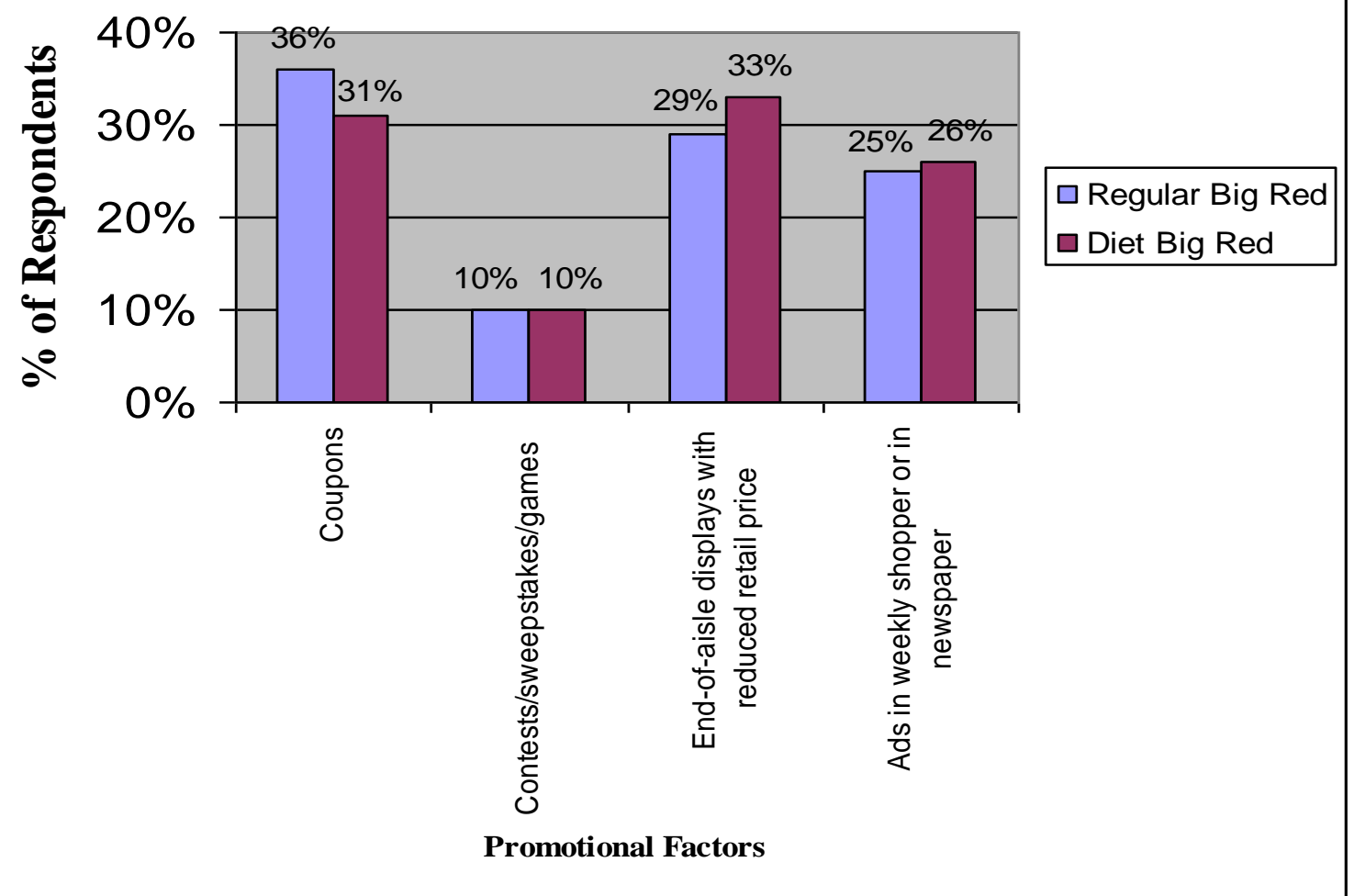


Figure 19: Q18 Which of the following promotional items have you recently seen or heard for Big Red products?

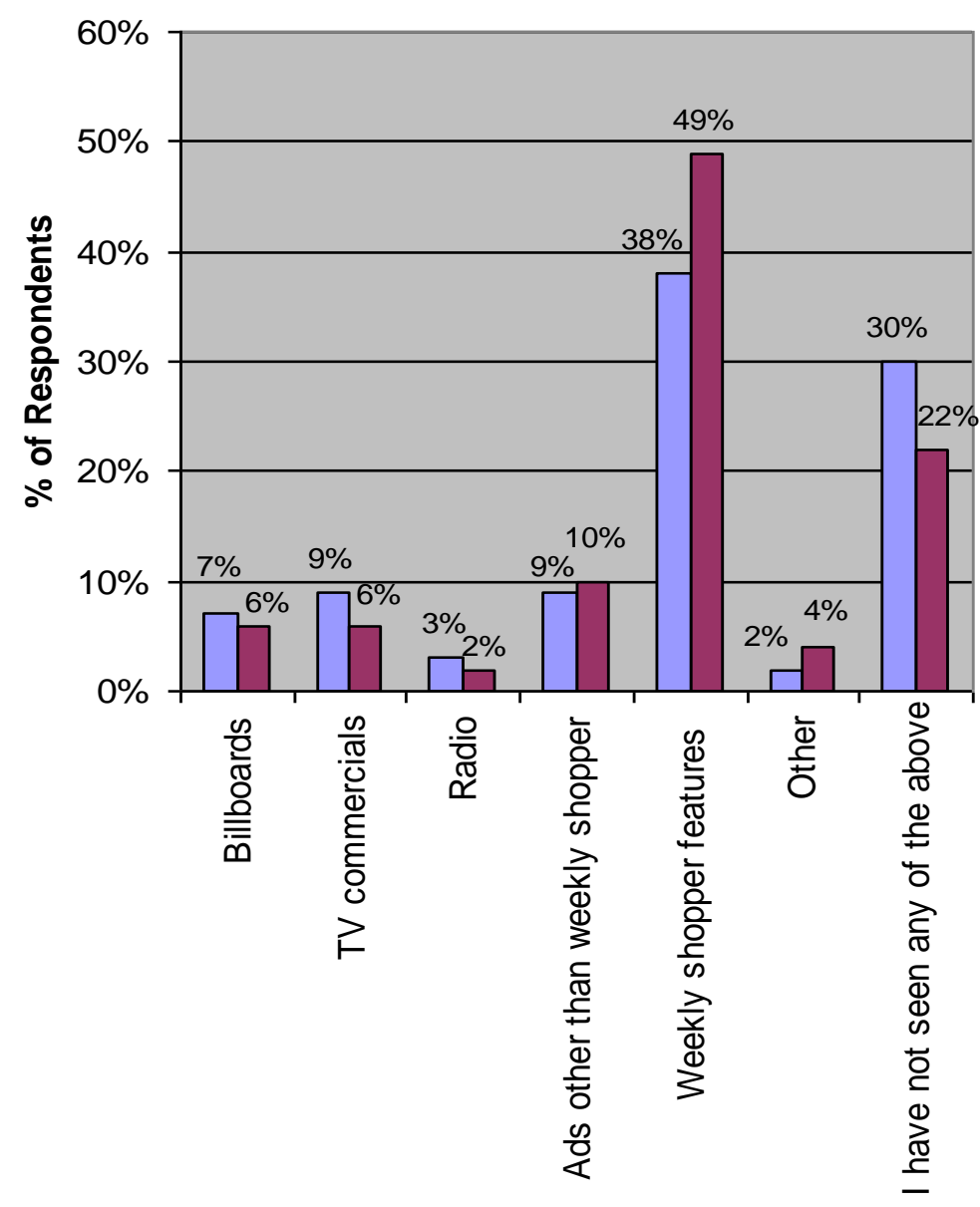

$\square$ Regular Big Red

$\square$ Diet Big Red

Awareness of Promotional Items 
Exhibit 10 Summary and Comments from Consumer Focus Group

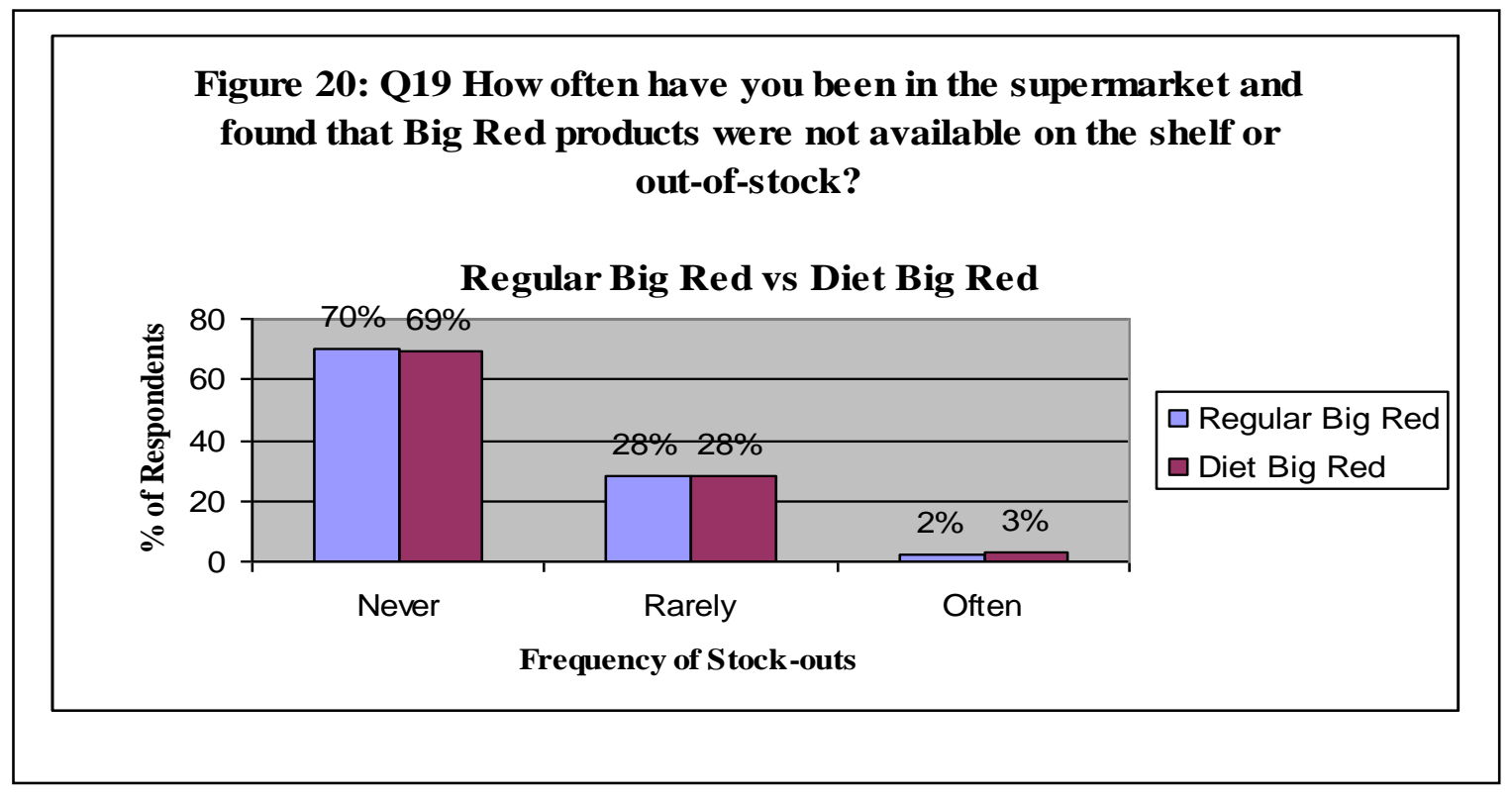

Figure 21: Q20 Do you find it difficult to locate Big Red products in the soft drink aisle of your supermarket?

Regular Big Red vs Diet Big Red

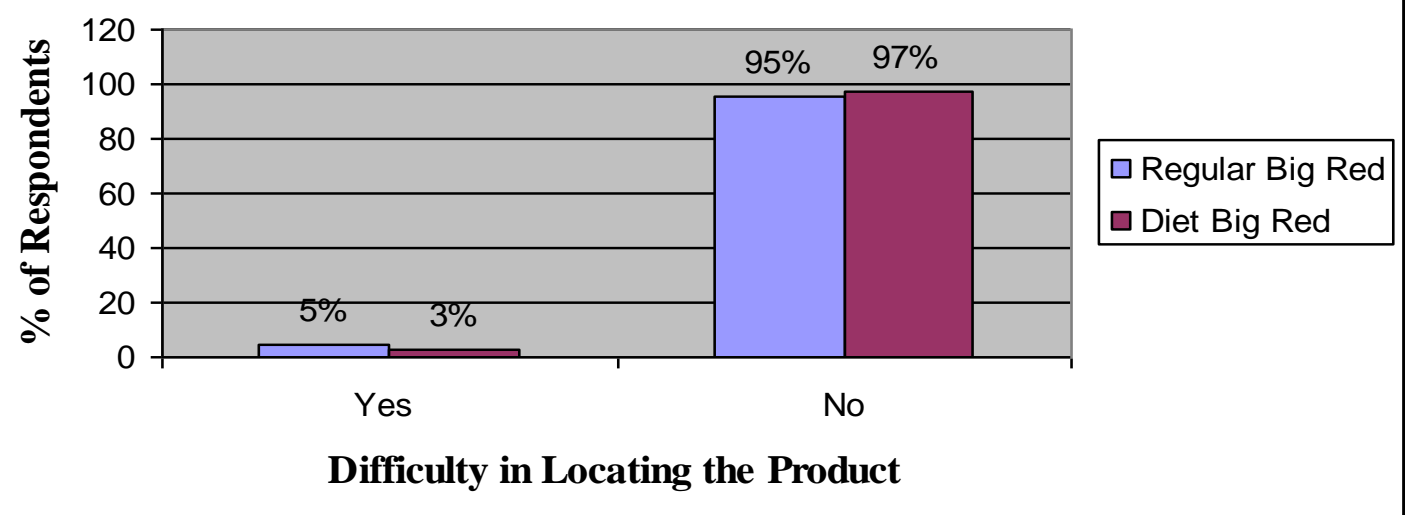

General Consumer Purchase Behavior and Lifestyle Issues:

- $\quad$ The participants indicated a strong preference for diet soft drinks.

- $\quad$ The brands most frequently purchased by participants included: Diet Big Red, Diet Dr. Pepper, Diet Pepsi, Diet Mountain Dew, Diet Ginger Ale, CR Mist, Diet Canada Dry, Diet Coke, Diet Root Beer, Diet Big K, and Diet Rite. 
- The stores where participants often purchased soft drinks included: Kroger, Meijers, Wal-Mart, Walgreen's, Speedway, Thornton's, and Rite-Aide. The participants said that the soft drinks purchased at these stores had to be on sale.

- $\quad$ Consumption of Diet Big Red was found to have increased among participants over the last 12 months.

Product and Packaging Issues:

The participants had a strong preference for soft drinks that contained Splenda as a sweetener. Specific comments included:

- "Diet Big Red stays true to the taste of Regular Big Red."

- "Not all diet drinks taste alike...I can't drink Diet Coke anymore"

- "Because I'm Diabetic, I prefer my diet drinks to have Splenda; I believe it makes them taste better"

- "too much aspartame makes me sick"

- "Splenda taste more like sugar, but not as sweet as sugar"

The participants displayed a strong brand loyalty to Big Red products with half of the participants indicating brand loyalty to Big Red. Big Red and Diet Big Red were very popular.

Several participants were specifically brand loyal to products containing Splenda.

Big Red products held emotional significance with several participants due to the long time period they had been consuming the product.

The meaning of "brand loyalty" varied:

- "Diet Big Red is really good"

- "Diet Big Red and Big Red I stay with them....Coke raises my blood pressure"

- "It depends what is on sale and what the price is"

- "The taste is more important, I will stay with it if it tastes good"

- "They must earn my loyalty one can at a time"

- "I have recently become brand loyal but only to those containing Splenda."

Store brands were not found to be popular with the participants.

Splenda has contributed to increasing the consumption of Diet Big Red.

Participants had a difficult time describing the taste of Big Red. Some indicated that too much aspartame made them sick.

- $\quad$ "Everyone enjoys Splenda and I am glad that Diet Big Red contains Splenda, I think it makes it taste better and I buy more because of it."

- "I buy Diet Big Red because it no longer contains aspartame, which I think leaves a bad aftertaste."

- "Big Red has always tasted better in a glass bottle"

- "Diet Big Red goes flatter faster than most products"

- "My favorite way to drink Diet Big Red is with ice-cream"

- "Big Red tastes like red....it can't be narrowed down to a single thing"

- "It tastes like cream soda"

- "The taste has gotten better over the past few years"

- "I'm not a big cream soda person, but I do like Big Red"

- "You don't see people copying Big Red, you do see them copying other soft drinks"

- "Not many diet drinks taste good, only Diet Big Red tastes good" 
In comparison to Caffeine Free Big Red consumers were not able to notice a different taste in Regular or Diet Big Red. Nearly all participants said it taste the same, with one participant speaking up that it should because caffeine does not have a taste.

Big Red should come out with a Diet Cherry Vanilla Float. Many participants expressed interest in the Cherry Vanilla Float and expressed interest in new flavors.

- "Big Red should introduce other flavors, I like their red cream soda but would like more variety"

- "They [Big Red] should be more creative and come out with other flavors"

- $\quad$ "I would like to see other cream soda flavors with the Big Red brand name...that would give me more options to chose from"

- $\quad$ "Both Pepsi and Coke have an entire aisle full of different products...I think Big Red should try and introduce some new flavors for us because I do love their red cream soda tasting product"

\section{Pricing Issues:}

All participants stated that pricing was an influential factor in their purchasing decision. In comparison to other national brands such as Coke or Pepsi, participants felt that Big Red products were generally a fair price.

- "If it is not on sale I'll buy something else"

- II still buy Big Red products if they're not on sale, it's cheaper as opposed to driving to another location, plus chances are it will be on sale the next time I come.'

- $\quad$ 'If Big Red is not on sale and another of my favorite drinks is, I will still buy one 2-liter of Big Red and several of the ones on sale.'

Distribution and Merchandising Issues:

The majority of the participants purchase their Big Red products from the local grocery store as opposed to a convenience store because of price.

Normally when making purchases at convenience stores participants were traveling long distances or on the go and running errands around town.

One woman reported that she does not go to the convenience store when on the go an, instead, she purchases a 2-liter bottle that she keeps in her car with an available cup.

Most purchase their beverages at supermarkets unless the product is on sale at a convenience store.

- "It is usually cheaper at the grocery store."

- "I buy at convenience stores because it is convenient"

- "I never buy at convenience stores; it is too expensive"

- "You hate to buy the product at convenience store because it's too expensive"

- "I want my drink with me when I leave the house"

- "Your 2-liter bottles are less expensive, so I try to get 2 for 2"

- "I stop at the convenience stores to get Big Red when we are having chili if my wife forgot to buy it"

- "It tastes better in a bottle than a can"

In the past twelve months, all of the participants reported that they frequently encountered stock-outs for Big Red products when they were at the grocery store.

If Big Red is available, the participants indicated that they often stock-up in case it is not available the next time they are in the store.

Many participants blamed the stores for the distribution problems; however, some group members understood that it was a problem with the distributor.

If Big Red products are not available some participants would drive to a different store to buy the product. 
When Big Red products are reduced in price many of the participants increase the amount that they buy. All participants were able to recall the exact price and package size of the Big Red product they last purchased and were very sensitive to price. However, the participants stated that Big Red's prices offered a fair value to the consumer.

Participants also indicated that other products from the same distributor are not necessarily out-of-stock when Big Red is out-of-stock.

- $\quad$ "I can rarely find Diet Caffeine Free Big Red 24-packs, so I end up purchasing the 12-can package."

- $\quad$ "It is generally out-of-stock at Kroger particularly the first of the month and they should know this and get more of the product"

- "You can't sell it if it is not there"

- "They told me that they don't deliver the product that's why they don't have it"

- "I try to buy more of Big Red when they have it because they are often out-of-stock"

- $\quad$ "I can't find it because they don't buy enough of it, and nothing aggravates me more than finding it not on the shelf and asking a stock person to go look for it and they come back and always tell me there is nothing in the back room"

- "They say that Pepsi has about 8 racks and Diet Big Red only has 1 rack because it is new to the market"

- "Since Big Red products has been around since 1937, they should have everything worked out by now, they shouldn't have empty shelves where their products should be."

\section{Advertising and Promotional Issues:}

Participants were concerned with the lack of advertising for Big Red products. The participants indicated that there is very little promotion or advertising awareness for Big Red products compared to other national brands of soft drinks.

Many participants felt that Big Red should emphasize the popularity of Splenda and use Splenda as a selling point in their advertising.

Participants also indicated that they would like to see more of the following: newspaper ads, local cable television ads, radio, billboards, and especially a more detailed website.

- $\quad$ "You never see Big Red do any types of games like the other soft drinks,...they should have twist-off cap games, like Mountain Dew and Coke products do"

- $\quad$ "RC doesn't do any national advertising; it is just Pepsi or Coke, you never see any RC they don't advertise nationally"

- "Why not advertise where you do distribute the product"

- "Advertising on TV and push the Splenda"

- "maybe their advertising should be like Mountain Dew with the extreme sports"

Suggestions to increase consumption of Big Red with young people included advertising during movies. Participants said that young people would select Big Red over Coke if given to them. Make the product happy and appealing to the young. 


\section{NOTES}

